\title{
Aqueous humor and serum 25- Hydroxyvitamin D levels in patients with cataracts
}

\author{
Min-Chul Cho ${ }^{1,2}$, Rock-Bum Kim ${ }^{3}$, Ja-Young Ahn ${ }^{4}$, Woong-Sun Yoo ${ }^{2,4}$ and Seong-Jae Kim ${ }^{2,4^{*}}$ (D)
}

\begin{abstract}
Background: Serum 25-hydroxyvitamin D (25 $(\mathrm{OH})$ D) levels are associated with various pathologic ocular conditions. Few studies have assessed $25(\mathrm{OH}) \mathrm{D}$ concentrations in non-serum specimens, and none to date has assessed $25(\mathrm{OH}) \mathrm{D}$ concentrations in human aqueous humor and their association with ocular diseases. This study investigated the possible correlations between $25(\mathrm{OH}) \mathrm{D}$ concentrations in aqueous humor and serum and whether vitamin $\mathrm{D}$ concentrations in aqueous humor were associated with cataract.

Methods: This study prospectively enrolled 136 patients, including 87 with senile cataract and 49 with diabetic cataract, who underwent cataract surgery from January to November 2017. $25(\mathrm{OH}) \mathrm{D}$ was measured in aqueous humor and serum specimens collected from all patients, and their correlation was analyzed statistically. Clinical and laboratory data, including the results of ophthalmologic examinations, were compared in the two groups of cataract patients.

Results: No correlation was observed between $25(\mathrm{OH}) \mathrm{D}$ concentrations in aqueous humor and serum $(P=0.381)$. $25(\mathrm{OH}) \mathrm{D}$ concentrations in aqueous humor were significantly higher in patients with diabetic than senile cataract $(P=0.006)$. Multivariate logistic regression analysis showed that the adjusted odds ratio for diabetic cataract for the highest compared with the lowest quartile of $25(\mathrm{OH}) \mathrm{D}$ concentration in aqueous humor was $4.36 \mathrm{ng} / \mathrm{ml}(95 \%$ confidence interval [Cl]: $1.33-14.34 \mathrm{ng} / \mathrm{ml} ; P=0.015)$. Multivariate linear regression analysis showed that $25(\mathrm{OH}) \mathrm{D}$ concentration in aqueous humor was $2.68 \mathrm{ng} / \mathrm{ml}(95 \% \mathrm{Cl}: 0.34-5.01 \mathrm{ng} / \mathrm{ml} ; P=0.025)$ higher in patients with diabetic than senile cataract.
\end{abstract}

Conclusions: $25(\mathrm{OH}) \mathrm{D}$ concentrations in aqueous humor and serum did not correlate with each other. Higher 25(OH) $D$ level in aqueous humor was associated with diabetic cataract. These findings suggest that studies of vitamin $D$ levels in patients with ocular conditions should include measurements of vitamin D levels in aqueous humor.

Keywords: 25-hydroxyvitamin D, Aqueous humor, Cataract

\section{Background}

Vitamin D is a multifunctional molecule that plays significant roles in various biological functions, including the regulation of calcium homeostasis [1]. For example, vitamin $\mathrm{D}$ has been shown to reduce inflammatory mediators and have anti-oxidative activities [2]. Many

\footnotetext{
* Correspondence: maya12kim@naver.com

${ }^{2}$ Institute of Health Science, Gyeongsang National University, Jinju, South Korea

${ }^{4}$ Department of Ophthalmology, Gyeongsang National University Hospital and Gyeongsang National University College of Medicine, 79 Gangnam-ro, Jinju-si, Gyeongsangnam-do 52727, South Korea

Full list of author information is available at the end of the article
}

studies show an inverse relationship between vitamin D concentrations and chronic diseases associated with chronic inflammation, including diabetes mellitus, hypertension, heart disease, multiple sclerosis, schizophrenia, and rheumatoid arthritis [3-6].

Two forms of vitamin D have been identified: D2 (ergocalciferol) and D3 (cholecalciferol). Vitamin D status is determined primarily by measuring serum concentration of total 25-hydroxyvitamin D $(25(\mathrm{OH}) \mathrm{D})$, which includes both forms of vitamin D [7]. Although there is no consensus regarding optimal concentrations of total $25(\mathrm{OH}) \mathrm{D}$, individuals with serum concentrations under

(C) The Author(s). 2020 Open Access This article is distributed under the terms of the Creative Commons Attribution 4.0 International License (http://creativecommons.org/licenses/by/4.0/), which permits unrestricted use, distribution, and 
$20 \mathrm{ng} / \mathrm{mL}(50 \mathrm{nmol} / \mathrm{L})$ are generally considered vitamin D deficient and those with serum concentrations of 20$30 \mathrm{ng} / \mathrm{mL}(50-75 \mathrm{nmol} / \mathrm{L})$ are generally considered vitamin D insufficient [8-10]. LC-MS/MS is generally considered the gold standard for the measurement of $25(\mathrm{OH}) \mathrm{D}[11]$, but this method has several limitations preventing its use in general clinical laboratories. Thus, $25(\mathrm{OH}) \mathrm{D}$ is usually measured by automated equipment using a chemiluminescence-based method, which has shown good correlation with LC-MS/MS [11, 12].

Serum $(25(\mathrm{OH}) \mathrm{D})$ status may also be associated with pathologic ocular conditions. For example, serum vitamin D levels are reported to influence the development of ocular pathologies, such as myopia, age-related macular degeneration, diabetic retinopathy, uveitis, and dry eye syndrome [13-16]. Few studies, however, have investigated vitamin D levels in non-serum specimens such as tears [17-19], and none to date has directly measured vitamin D levels in human aqueous humor specimens.

Aqueous humor is a clear liquid that occupies the anterior segments of the eye. Although aqueous humor derives from blood plasma, its composition differs from serum, with aqueous humor having lower concentrations of protein and glucose and higher concentrations of ascorbic acid than serum. Aqueous humor provides oxygen and nutrients to ocular tissues and removes their waste products. Because the lens is an avascular internal ocular organ supplied by the aqueous humor with oxygen and nutrients, changes in the composition of aqueous humor can lead to cataracts. Studies have reported that changes in several factors in the anterior chamber of the eye are associated with cataract development [20-23].

Cataract is a sight-threatening ocular disease, responsible for more than $30 \%$ of all cases of blindness [24, 25]. Factors that increase the risk of cataract include aging, diabetes mellitus, eye trauma, exposure to ultraviolet light, drug use, and other ocular diseases [26-28]. Several epidemiological studies suggest that the serum concentration of vitamin D is associated with the development of age-related or diabetic cataract $[16,29]$. To date, however, studies have only examined the association between serum vitamin D levels and ocular diseases, with no studies to our knowledge assessing the range of $25(\mathrm{OH}) \mathrm{D}$ concentrations in human aqueous humor or the association between vitamin D concentrations in aqueous humor and cataract. This study therefore measured $25(\mathrm{OH}) \mathrm{D}$ concentrations in aqueous humor and serum samples from 136 patients with cataract, including 87 with senile cataract and 49 with diabetic cataract. The primary objective was to determine the correlation between $25(\mathrm{OH}) \mathrm{D}$ concentrations in aqueous humor and serum. This study also analyzed the association of vitamin D concentrations in aqueous humor with cataract.

\section{Methods}

\section{Study design}

This was a prospective study conducted at Gyeongsang National University Hospital, Jinju, Korea. Aqueous humor and serum samples were collected from 136 patients who underwent cataract surgery between January and November 2017. The study was approved by the Gyeongsang National University Hospital Institutional Review Board (2017-01-011). The study protocol confirmed to the tenets of the Declaration of Helsinki, and all patients provided written informed consent before participating.

\section{Ophthalmic examinations and cataract surgery with anterior chamber paracentesis}

After a complete medical history was taken, all participants underwent an ophthalmologic examination, including measurements of best-corrected visual acuity and intraocular pressure, as well as slit lamp biomicroscopy, and fundus examination. The enrolled patients were divided into those with senile and diabetic cataracts. Patients with complicated cataracts, including those with cataracts due to eye trauma, uveitis, or longterm use of steroids, and those who had undergone previous ophthalmic surgery were excluded. The diabetic cataract group included patients with well-controlled diabetes (hemoglobin $\mathrm{A} 1 \mathrm{C}<7 \%$ ) with non-proliferative diabetic retinopathy; patients with proliferative diabetic retinopathy and those who had undergone vitrectomy or intravitreal injection were excluded. Patients with diabetes and other ocular diseases (e.g., glaucoma or retinal disease) were excluded from the senile cataract group. Cataract type and severity were graded using the Lens Opacity Classification System III. Anterior chamber volume (ACV), axial anterior chamber depth (ACD), and central corneal thickness (CCT) were measured using the Pentacam system (Oculus Inc., Wetzlar, Germany). Ocular biometry was performed using the IOL Master system (IOL Master 500, Carl Zeiss Meditec, Jena, Germany), which uses signals from the tear film and retinal pigment epithelium to measure axial length (AL). Corneal endothelial cell number and morphology were examined by CellChek XL (Konan Medical, Irvine, CA, USA). Retinal macular thickness was measured using spectralis OCT volume scans (Heidelberg Engineering, Heidelberg, Germany). Patients underwent slit lamp examination was performed to determine tear breakup time (TBUT) and the Schirmer test. Patients were also administered questionnaires to assess their occupation, average daily activity, and use of vitamin D supplements.

All cataract surgeries were performed by a single experienced surgeon (S.J.K.). After instillation of topical anesthesia, approximately $150-200 \mu \mathrm{L}$ of aqueous humor was collected according to anterior chamber depth with 
a 30-gauze tuberculin syringe through the clear cornea near the limbus before making main incision $(2.2 \mathrm{~mm})$, followed by completion of cataract surgery.

\section{Laboratory analysis}

All aqueous humor samples were taken to the laboratory immediately after collection, and their vitamin $\mathrm{D}$ concentrations were measured. By contrast, all serum specimens were stored at $-70^{\circ} \mathrm{C}$ until analyzed.

Concentrations of total 25(OH) D were measured using Elecsys Vitamin D Total Kits with the Cobas e602 module (Roche Diagnostics, Mannheim, Germany), an electrochemiluminescence assay that measures two forms of 25-hydroxy vitamin $\mathrm{D}\left(\mathrm{D}_{2}\right.$ and $\left.\mathrm{D}_{3}\right)$ in three steps. During the first step, bound $25(\mathrm{OH}) \mathrm{D}$ is released from the vitamin $\mathrm{D}$ binding protein (VDBP). In the second step, the released $25(\mathrm{OH}) \mathrm{D}$ binds to added ruthenium labeled VDBP to form a complex. In the third step, the unbound ruthenium labeled VDBP is removed by the addition of streptoavidin-coated microparticles and $25(\mathrm{OH}) \mathrm{D}$ is labeled with biotin. Application of voltage to the electrode then induces the ruthenimun labeled VDBP-25(OH) D complex to emit chemiluminescence, which is measured with a photomultiplier. The signals produced were inversely proportional to the $25(\mathrm{OH}) \mathrm{D}$ concentrations in the original samples. Measured concentrations are standardized using an instrument-generated calibration curve [30]. The volume of each aqueous humor collected from the anterior chamber was approximately $150-200 \mu \mathrm{L}$ and the actual volume analyzed by the Elecsys kits was $40 \mu \mathrm{L}$.

\section{Statistical analysis}

Categorical data are presented as number (\%), and continuous data as median (interquartile range; IQR) because most of the continuous data did not satisfy the normality and homoscedasticity assumptions of the Shapiro-Wilk test and Leven's F test, respectively. Spearman's rank correlation analysis was used to assess the correlation between vitamin $\mathrm{D}$ concentrations in serum and aqueous humor. The concentrations of vitamin $\mathrm{D}$ in aqueous humor and serum were compared in the senile and diabetic cataract groups using the MannWhitney U test or the Kruskal-Wallis test.

The proportions of variables in the senile and diabetic cataract groups were compared using Fisher's exact test. Multivariate logistic regression analysis was performed to calculate the adjusted odds ratio (OR) of diabetic cataract relative to senile cataract. The adjusted variables selected for the multivariate analysis were those with $P$ values $<0.15$ in univariate analysis and without multiple collinearity. In addition, clinically important variables were included in the multivariate analysis for adjustment. The adjusted OR of aqueous humor vitamin D was calculated separately based on quartiles (Model 1) and as a continuous variable (Model 2).

Factors affecting the vitamin $\mathrm{D}$ concentrations in aqueous humor and serum were assessed by multivariate linear regression analysis using covariates with $P$ values $\leq 0.15$ in univariate analysis as well as covariates related to serum vitamin $\mathrm{D}$ concentration. Because the concentrations of vitamin $\mathrm{D}$ in aqueous humor and serum did not satisfy the normality assumption, the data were transformed by the fractional rank probability method [31].

All statistical analyses were performed with SAS version 9.4 software (SAS Institute Inc., Cary, NC, USA). A two tailed $P$ value $<0.05$ was considered statistically significant.

\section{Results}

\section{Subject characteristics}

The present study enrolled 136 patients, 87 with senile cataract and 49 with diabetic cataract; their demographic and clinical characteristics are shown in Table 1 . Vitamin D concentrations were significantly higher in men than in women, both in aqueous humor (11.5 vs. $7.5 \mathrm{ng} / \mathrm{mL}, P=0.010)$ and serum $(20.1$ vs. $14.2 \mathrm{ng} / \mathrm{mL}$, $P=0.02$ ). In addition, vitamin $\mathrm{D}$ concentration in aqueous humor was significantly higher in patients with diabetic than with senile cataract $(12.6$ vs. $8.8 \mathrm{ng} / \mathrm{mL}$, $P=0.006)$. There were no other significant differences in demographic and clinical factors between the two groups (all $P>0.05$ ).

Tables 2 and 3 summarize the proportional differences in each factor according to the type of cataract. Most clinical factors and ophthalmological characteristics, such as sex, age, average daily outdoor activity time, occupation, and use of vitamin D supplements, did not differ significantly between the groups of patients with senile and diabetic cataract (Table 2). The prevalence of hypertension was significantly higher in patients with diabetic than senile cataract $(P=0.012)$, whereas the percentage of patients with AL $>24 \mathrm{~mm}$ was significantly higher in the senile cataract than in the diabetic cataract group $(P=0.003$; Table 3$)$.

\section{Total $25(\mathrm{OH})$ concentrations in aqueous humor and serum}

The median (IQR) 25(OH) D concentration was 10.3 $(5.5-16) \mathrm{ng} / \mathrm{mL}$ in aqueous humor and 15.6 (11.6-25.8) $\mathrm{ng} / \mathrm{mL}$ in serum (Table 1). Measurements using the Cobas e602 module were possible if the sample volume was $>400 \mu \mathrm{L}$ (data not shown). 25(OH) D concentrations in aqueous humor and serum did not show significant correlation $(P=0.381$; Fig. 1$)$. Univariate analysis showed that sex and type of cataract were factors related to $25(\mathrm{OH}) \mathrm{D}$ concentration in aqueous humor and that 
Table 1 Relationships of demographic and clinical characteristics with vitamin D levels in aqueous humor and serum from patients with cataract

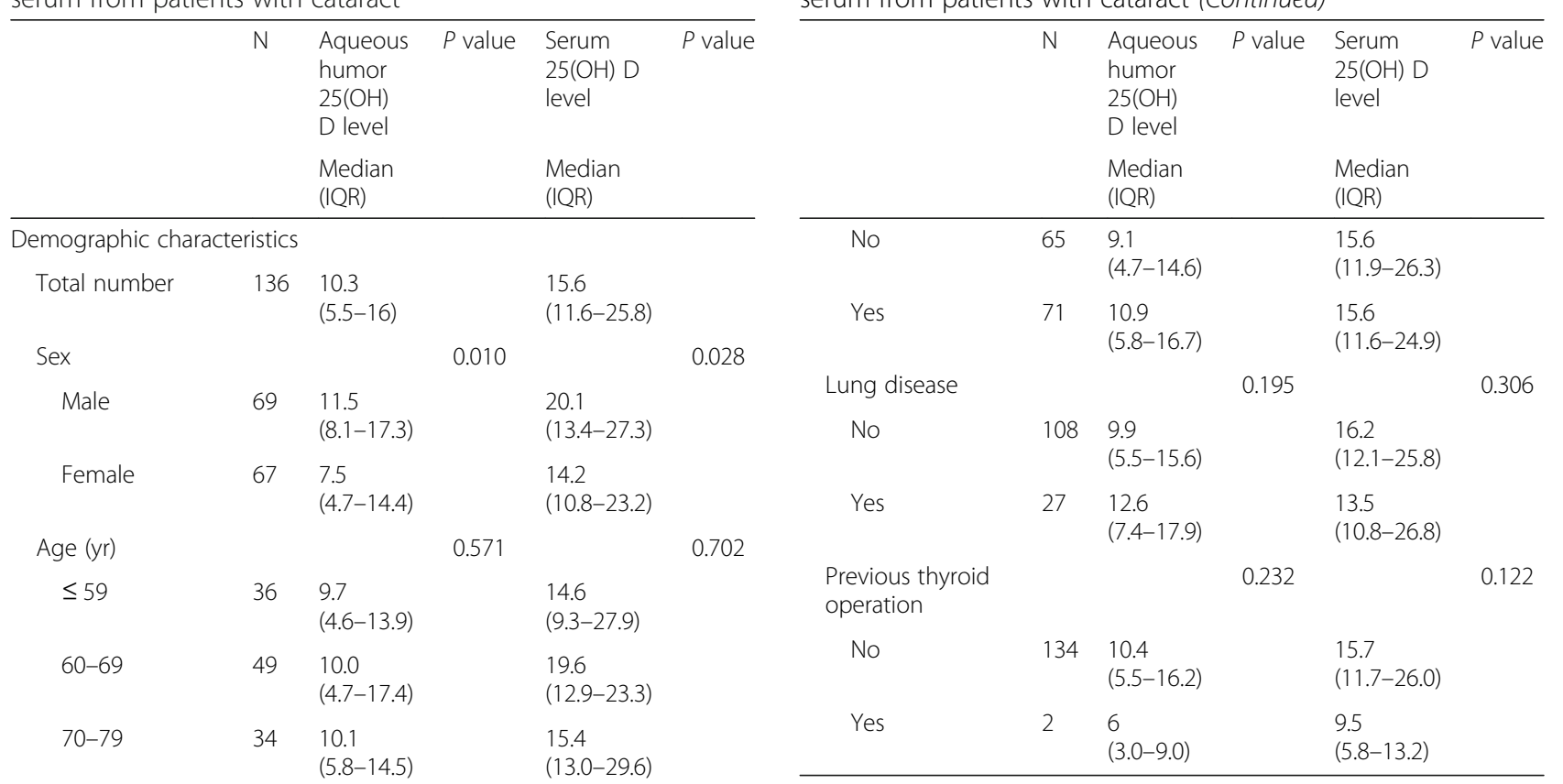

Table 1 Relationships of demographic and clinical characteristics with vitamin D levels in aqueous humor and serum from patients with cataract (Continued)
13.6

$(10.7-27.8)$

$0.146 \quad 0.432$

Average outdoor

activity time

(hr/day)

$<2$

$2-6$

$\geq 6$

Occupation

None

Housewife/clerk

Farmer/outdoor

worker

Vitamin D

supplementation

No

Yes

$$
\begin{array}{ll}
127 & 10.4 \\
& (5.4-16.7)
\end{array}
$$$$
9 \quad 8.1
$$$$
(5.8-12.0)
$$

Clinical characteristics

Type of cataract

Senile

Diabetic

$$
\begin{array}{ll}
87 & 8.8 \\
& (4.4-13.6) \\
49 & 12.6 \\
& (7.5-20.2)
\end{array}
$$

Hypertension

14.6

$(11.1-23.2)$

16.1

(12.5-28.4)

20.1

(12.0-23.6)

0.373

0.185

15.2

(11.5-23.8)

14.6

$(10.8-23.4)$

20.1

$(12.9-29.6)$

$0.451-0.144$

15.3

$(11.6-24.1)$

29.2

$(15.2-30.1)$

0.006

16.1

$(11.6-26.3)$

14.7

$(12.4-23.2)$

0.276 sex was the only factor related to serum $25(\mathrm{OH}) \mathrm{D}$ concentration (Table 1). The median concentration was 4.0 $\mathrm{ng} / \mathrm{mL}$ lower in women than in men $(P=0.010)$ and 3.8 $\mathrm{ng} / \mathrm{mL}$ lower in patients with senile than diabetic cataract $(P=0.006)$. Median $(\mathrm{IQR})$ of aqueous humor vitamin D levels according to nuclear color (NC) $0-1,2-3$ and 4-5 stages were $12.8(8.8-14.3), 10.4(5.8-16.3)$ and 8.2(4.4-16.2) $(P=0.447)$, respectively. And the median (IQR) of aqueous humor vitamin $\mathrm{D}$ levels according to nuclear opalescence (NO) $0-1,2-3$ and 4-5 stages were 12.9(4.7-14.0), 10.4(5.8-16.3) and 8.4(4.5-15.3) $\quad(P=$ 0.702 ), respectively (data not shown).

\section{Comparison of ophthalmologic examination results and $25(\mathrm{OH})$ concentrations in aqueous humor and serum according to the type of cataract}

Ophthalmologic examination results and total $25(\mathrm{OH})$ concentrations in aqueous humor and serum were also compared in groups of patients with diabetic and senile cataract (Table 3). None of the ophthalmologic examination results differed significantly in these two groups (all $P>0.05)$. When $25(\mathrm{OH}) \mathrm{D}$ concentrations in aqueous humor and serum were analyzed by quartile, diabetic cataract showed the highest proportion (54.6\%) in the fourth quartile $(\mathrm{Q} 4)$, with the highest concentration of $25(\mathrm{OH}) \mathrm{D}$ in aqueous humor $(P=0.034) .25(\mathrm{OH}) \mathrm{D}$ concentrations in aqueous humor differed significantly in the groups of patients with senile and diabetic cataract $(P=0.006$; Fig. 2$)$. 
Table 2 Demographic and clinical characteristics of patients with senile and diabetic cataract

\begin{tabular}{|c|c|c|c|c|}
\hline & N (\%) & Type of $c$ & taract & $P$ value \\
\hline & & $\begin{array}{l}\text { Senile, } \\
\text { N (\%) }\end{array}$ & $\begin{array}{l}\text { Diabetic, } \\
N(\%)\end{array}$ & \\
\hline $\begin{array}{l}\text { Demographic } \\
\text { characteristics }\end{array}$ & & & & \\
\hline Total number & $136(100.0)$ & $87(64.0)$ & $49(36.0)$ & \\
\hline Sex & & & & 0.479 \\
\hline Male & $69(50.7)$ & $42(60.9)$ & $27(39.1)$ & \\
\hline Female & $67(49.3)$ & $45(67.2)$ & $22(32.8)$ & \\
\hline Age (yr) & & & & 0.310 \\
\hline$\leq 59$ & $36(26.5)$ & $27(75.0)$ & $9(25.0)$ & \\
\hline $60-69$ & $49(36.0)$ & $28(57.1)$ & $21(42.9)$ & \\
\hline $70-79$ & $34(25.0)$ & $20(58.8)$ & $14(41.2)$ & \\
\hline$\geq 80$ & $17(12.5)$ & $12(70.6)$ & $5(29.4)$ & \\
\hline $\begin{array}{l}\text { Average outdoor } \\
\text { activity time (hr/day) }\end{array}$ & & & & 0.303 \\
\hline$<2$ & $51(37.5)$ & $34(66.7)$ & $17(33.3)$ & \\
\hline $2-6$ & $61(44.9)$ & $41(67.2)$ & $20(32.8)$ & \\
\hline$\geq 6$ & $24(17.6)$ & $12(50.0)$ & $12(50.0)$ & \\
\hline Occupation & & & & 0.330 \\
\hline None & $48(35.3)$ & $27(56.3)$ & $21(43.8)$ & \\
\hline Housewife/clerk & $49(36.0)$ & $32(65.3)$ & $17(34.7)$ & \\
\hline $\begin{array}{l}\text { Farmer/outdoor } \\
\text { worker }\end{array}$ & $39(28.7)$ & $28(71.8)$ & $11(28.2)$ & \\
\hline $\begin{array}{l}\text { Vitamin D } \\
\text { supplementation }\end{array}$ & & & & 0.722 \\
\hline No & $127(93.4)$ & $82(64.6)$ & 45 (35.4) & \\
\hline Yes & $9(6.6 .0)$ & $5(55.6)$ & $4(44.4)$ & \\
\hline Clinical characteristics & & & & \\
\hline Hypertension & & & & 0.012 \\
\hline No & $65(47.8)$ & $49(75.4)$ & $16(24.6)$ & \\
\hline Yes & $71(52.2)$ & $38(53.5)$ & $33(46.5)$ & \\
\hline Lung disease & & & & 0.506 \\
\hline No & $108(79.4)$ & $67(62.0)$ & $41(38.0)$ & \\
\hline Yes & $27(19.9)$ & $19(70.4)$ & $8(29.6)$ & \\
\hline $\begin{array}{l}\text { Previous thyroid } \\
\text { operation }\end{array}$ & & & & 1.000 \\
\hline No & $134(98.5)$ & $86(64.2)$ & 48 (35.8) & \\
\hline Yes & $2(1.5)$ & $1(50.0)$ & $1(50.0)$ & \\
\hline
\end{tabular}

Multivariate logistic regression analysis of factors associated with diabetic cataract

Factors included in the multivariate logistic regression analysis were $25(\mathrm{OH})$ D concentration in aqueous humor, hypertension, and AL, all of which were significant in univariate analysis, and sex, age, and average daily outdoor activity time, which were considered clinically important. When $25(\mathrm{OH})$ D concentrations in
Table 3 Ophthalmologic characteristics and 25(OH) concentrations in patients with senile and diabetic cataract

\begin{tabular}{llll}
\hline$N(\%)$ & \multicolumn{2}{l}{ Type of cataract } & $P$ value \\
\cline { 2 - 3 } & Senile, & Diabetic, \\
& $N(\%)$ & $N(\%)$ \\
\hline
\end{tabular}

Ophthalmologic examination results

BCVA (Snellen)
$\leq 20 / 125$
$20 / 100-20 / 40$
$\geq 20 / 32$
IOP (mmHg)
$\leq 20$
$>20$
NC
$0-1$
$2-3$
$4-5$
NO
$0-1$
$2-3$
$4-5$
PSC
$0-1$
$2-3$
$4-5$

Central macular thickness $(\mu \mathrm{m})$

$\leq 250$
$250-300$

Schirmer $(\mathrm{mm})$

$\leq 10$

$>10$

Spherical equivalent (D)

$\leq-3.0$
$-3.0-0.0$
$0.0-3.0$
$>3.0$

Central corneal thickness $(\mu \mathrm{m})$

$$
\begin{aligned}
& \leq 520 \\
& >520
\end{aligned}
$$

ECC (cells $/ \mathrm{mm}^{2}$ )

$$
\begin{aligned}
& \leq 1000 \\
& 1000-2000
\end{aligned}
$$$$
>2000
$$

1.000

$$
\begin{array}{lll}
14(10.3) & 9(64.3) & 5(35.7) \\
61(44.9) & 38(62.3) & 23(37.7) \\
41(30.1) & 25(61.0) & 16(39.0)
\end{array}
$$

1.000

$131(96.3) \quad 84(64.1) \quad 47(35.9)$

$5(3.7) \quad 3(60.0) \quad 2(40.0)$

$12(8.8) \quad 9(75.0) \quad 3(25.0)$

$99(72.8) \quad 59(59.6) \quad 40(40.4)$

$25(18.4) \quad 19(76.0) \quad 6(24.0)$

0.135

$6(4.4) \quad 5(83.3) \quad 1(16.7)$

$106(77.9) \quad 63(59.4) \quad 43(40.6)$

$24(17.6) \quad 19(79.2) \quad 5(20.8)$

$94(69.1) \quad 66(70.2) \quad 28(29.8)$

$37(27.2) \quad 18(48.7) \quad 19(51.4)$

$5(3.7) \quad 3(60.0) \quad 2(40.0)$

0.534

$28(20.6) \quad 18(64.3) \quad 10(35.7)$

$69(50.7) \quad 41(59.4) \quad 28(40.6)$

$28(20.6) \quad 20(71.4) \quad 8(28.6)$

0.395

$33(24.3) \quad 17(51.5) \quad 16(48.5)$

$70(51.5) \quad 43(61.4) \quad 27(38.6)$

0.186

$\begin{array}{lll}34(25) & 26(76.5) & 8(23.5) \\ 53(39) & 29(54.7) & 24(45.3) \\ 32(23.5) & 20(62.5) & 12(37.5) \\ 1(0.7) & 1(100.0) & 0(0.0)\end{array}$

0.675

$31(22.8) \quad 21(67.7) \quad 10(32.3)$

$105(77.2) \quad 66(62.9) \quad 39(37.1)$

0.468 
Table 3 Ophthalmologic characteristics and 25(OH) concentrations in patients with senile and diabetic cataract (Continued)

\begin{tabular}{|c|c|c|c|c|}
\hline & \multirow[t]{2}{*}{$\mathrm{N}(\%)$} & \multicolumn{2}{|c|}{ Type of cataract } & \multirow[t]{2}{*}{$P$ value } \\
\hline & & $\begin{array}{l}\text { Senile, } \\
\text { N (\%) }\end{array}$ & $\begin{array}{l}\text { Diabetic, } \\
\text { N (\%) }\end{array}$ & \\
\hline Axial length (mm) & & & & 0.003 \\
\hline $20-24$ & 95 (69.9) & $53(55.8)$ & $42(44.2)$ & \\
\hline$\geq 24$ & $41(30.1)$ & $34(82.9)$ & $7(17.1)$ & \\
\hline $\begin{array}{l}\text { Anterior chamber } \\
\text { depth }(\mathrm{mm})\end{array}$ & & & & 0.203 \\
\hline$\leq 2$ & $11(8.1)$ & $5(45.5)$ & $6(54.6)$ & \\
\hline $2-3$ & $93(68.4)$ & $58(62.4)$ & 35 (37.6) & \\
\hline$>3$ & $32(23.5)$ & $24(75.0)$ & $8(25.0)$ & \\
\hline $\begin{array}{l}\text { Anterior chamber } \\
\text { volume }\left(\mathrm{mm}^{3}\right)\end{array}$ & & & & 0.368 \\
\hline$\leq 100$ & $33(24.3)$ & $19(57.6)$ & $14(42.4)$ & \\
\hline $100-150$ & $69(50.7)$ & $43(62.3)$ & $26(37.7)$ & \\
\hline$>150$ & $34(25.0)$ & $25(73.5)$ & $9(26.5)$ & \\
\hline \multicolumn{5}{|c|}{$\begin{array}{l}25(\mathrm{OH}) \mathrm{D} \text { concentrations } \\
\text { (in quartiles, } \mathrm{ng} / \mathrm{mL} \text { ) }\end{array}$} \\
\hline Serum & & & & 0.686 \\
\hline Q1 ( $\leq 11.78)$ & $35(25.7)$ & $23(65.7)$ & $12(34.3)$ & \\
\hline Q2 (11.78-16.04) & $36(26.5)$ & $20(55.6)$ & $16(44.4)$ & \\
\hline Q3 (16.04-25.81) & $31(22.8)$ & $21(67.7)$ & $10(32.3)$ & \\
\hline Q4 (>25.81) & $34(25.0)$ & $23(67.7)$ & $11(32.4)$ & \\
\hline Aqueous humor & & & & 0.034 \\
\hline $\mathrm{Q} 1(\leq 5.5)$ & $35(25.7)$ & $27(77.1)$ & $8(22.9)$ & \\
\hline Q2 (5.5-10.43) & $35(25.7)$ & $21(60.0)$ & $14(40.0)$ & \\
\hline Q3 (10.43-16.16) & $33(24.3)$ & $24(72.7)$ & $9(27.3)$ & \\
\hline Q4 (>16.16) & $33(24.3)$ & $15(45.5)$ & $18(54.6)$ & \\
\hline
\end{tabular}

Abbreviations: 25(OH) D 25-hydroxyvitamin D, BCVA Best-corrected visual acuity, IOP Intraocular pressure, NC Nuclear color, NO Nuclear opalescence, PSC Posterior subcapsular, D Diopters, ECC Endothelial cell count

aqueous humor were analyzed by quartile, diabetic cataract was significantly more frequent in Q4 than in Q1 subjects (Model 1: adjusted $\mathrm{OR}=4.36$; 95\% confidence interval $[\mathrm{CI}]=1.33-14.34 ; P=0.015)$, and diabetic cataract was significantly less frequent in subjects with $\mathrm{AL}$ $\geq 24 \mathrm{~mm}$ than $<24 \mathrm{~mm}$ (Model 1: adjusted $\mathrm{OR}=0.24$; 95\% CI $=0.08-0.70 ; P=0.009)$. In Model 2, in which $25(\mathrm{OH}) \mathrm{D}$ concentrations were analyzed as a continuous variable, a $5 \mathrm{ng} / \mathrm{mL}$ increase in $25(\mathrm{OH}) \mathrm{D}$ level in aqueous humor increased the OR for diabetic cataract by 1.2 (95\% CI $=0.38-1.91$; Table 4). No other factor was associated with diabetic cataract.

Multivariate linear regression analysis for determining factors affecting aqueous humor and serum $25(\mathrm{OH}) \mathrm{D}$ The factors affecting $25(\mathrm{OH}) \mathrm{D}$ level in aqueous humor were sex and type of cataract. $25(\mathrm{OH}) \mathrm{D}$ concentrations in aqueous humor were $2.79 \mathrm{ng} / \mathrm{mL}$ higher $(95 \% \mathrm{CI}=$ $0.53-5.05 \mathrm{ng} / \mathrm{mL}, P=0.016)$ in men than in women and $2.68 \mathrm{ng} / \mathrm{mL} \quad(95 \% \quad \mathrm{CI}=0.34-5.01 \mathrm{ng} / \mathrm{mL}, \quad P=0.025)$ higher in patients with diabetic than senile cataract (Table 5). In addition, serum vitamin $\mathrm{D}$ concentration was $7.8 \mathrm{ng} / \mathrm{mL}(95 \% \mathrm{CI}=0.34-5.01, P=0.025)$ higher in patients who did than did not take vitamin $\mathrm{D}$ supplements (Table 6).

\section{Discussion}

Serum 25(OH) D status has been associated with ocular health and disease [32], including with ocular surface diseases such as allergic conjunctivitis and dry eye [15, $33,34]$. Fewer studies, however, have investigated the association between ocular diseases and $25(\mathrm{OH}) \mathrm{D}$ in tear fluid. Furthermore, to our knowledge, no study to date has measured the concentration range of $25(\mathrm{OH}) \mathrm{D}$ in human aqueous humor or the association of $25(\mathrm{OH}) \mathrm{D}$ with ocular diseases such as cataract. The present study was therefore designed to determine whether $25(\mathrm{OH}) \mathrm{D}$ is present at measurable concentrations in human aqueous humor, whether $25(\mathrm{OH}) \mathrm{D}$ concentrations in aqueous humor and serum correlated, and whether $25(\mathrm{OH})$ $\mathrm{D}$ concentrations in aqueous humor were associated with cataract. We confirmed that $25(\mathrm{OH}) \mathrm{D}$ was present in human aqueous humor at a concentration directly measurable by an electrochemiluminescent assay used clinically to measure $25(\mathrm{OH}) \mathrm{D}$. However, the concentration of $25(\mathrm{OH}) \mathrm{D}$ in aqueous humor did not correlate with its concentration in serum. Interestingly, the present study found that $25(\mathrm{OH})$ D level was significantly higher in aqueous humor of patients with diabetic than with senile cataract.

The present study found no correlation between vitamin D concentrations in aqueous humor and serum of patients with cataract. Multivariate linear regression analysis showed that sex and type of cataract were factors affecting vitamin $\mathrm{D}$ concentration in aqueous humor. Specifically, 25(OH) D concentrations in aqueous humor were $2.79 \mathrm{ng} / \mathrm{mL}$ higher $(95 \% \mathrm{CI}=0.53-5.05 \mathrm{ng} / \mathrm{mL}, P=$ $0.016)$ in men than in women and $2.68 \mathrm{ng} / \mathrm{ml}(95 \% \mathrm{CI}=$ $0.34-5.01 \mathrm{ng} / \mathrm{mL}, P=0.025)$ higher in patients with diabetic than senile cataract. Serum $25(\mathrm{OH})$ D levels were also significantly higher in men than in women and lower in patients with severe than less severe nuclear cataract. The mean baseline serum vitamin $\mathrm{D}$ level in this study $(15.6 \mathrm{ng} / \mathrm{mL}$; range, $11.6-25.8 \mathrm{ng} / \mathrm{mL})$ was lower than in previous studies $(20-110 \mathrm{nmol} / \mathrm{L})$, although our finding that serum vitamin $\mathrm{D}$ levels were higher in men than in women was consistent with previous results [35]. Earlier studies also suggested that lower serum $25(\mathrm{OH})$ D levels were associated with a higher risk of nuclear cataract and significantly associated with an elevated risk of glaucoma in women [35, 36]. 


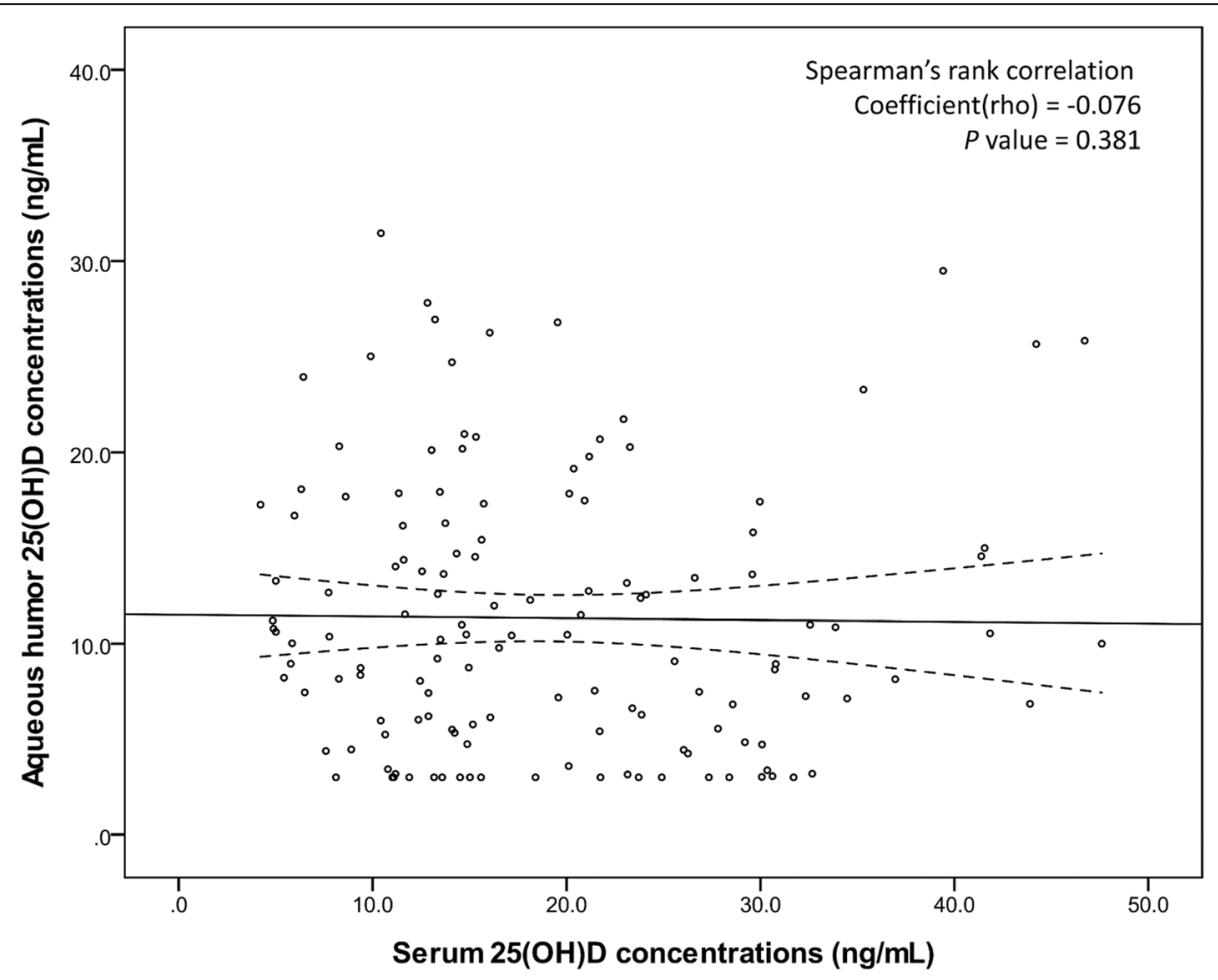

Fig. 1 Correlation between $25(\mathrm{OH}) \mathrm{D}$ concentrations in serum and aqueous humor

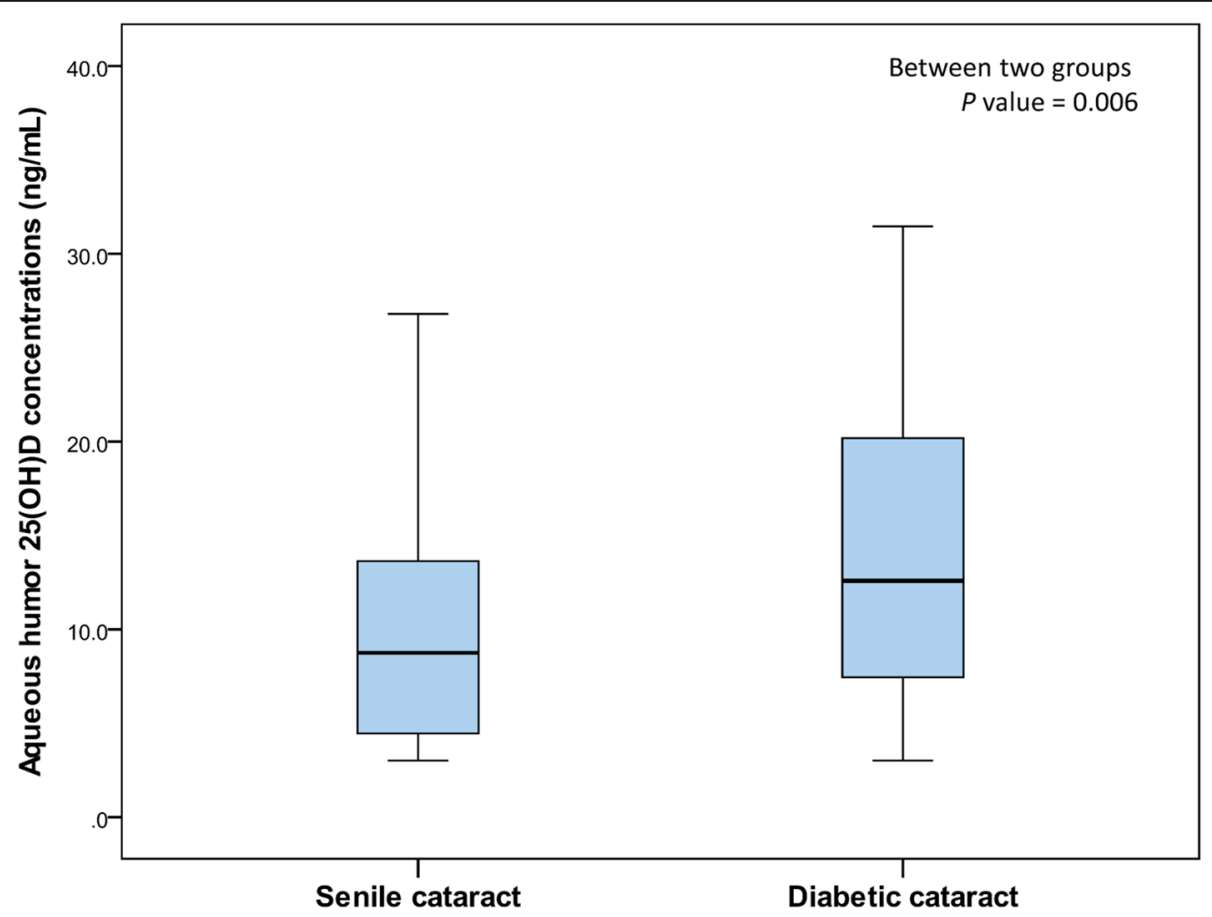

Fig. 2 Aqueous humor $25(\mathrm{OH}) \mathrm{D}$ concentrations in patients with senile and diabetic cataract 
Table 4 Associations between demographic and clinical characteristics and the likelihood of diabetic cataract after adjusting for confounders

\begin{tabular}{|c|c|c|c|c|c|c|}
\hline \multirow[t]{2}{*}{ Variables } & \multicolumn{3}{|l|}{ Model 1} & \multicolumn{3}{|l|}{ Model 2} \\
\hline & Adjusted OR & $95 \% \mathrm{Cl}$ & $P$ value & Adjusted OR & $95 \% \mathrm{Cl}$ & $P$ value \\
\hline Aqueous humor 25(OH) D level (per $5 \mathrm{ng} / \mathrm{mL}$ increase) & & & & 1.20 & $1.00-1.30$ & 0.005 \\
\hline \multicolumn{7}{|l|}{ Aqueous humor 25(OH) D Q1 (vs. $\leq 5.5 \mathrm{ng} / \mathrm{mL}$ ) } \\
\hline $5.5 \mathrm{ng} / \mathrm{mL}<\mathrm{Q} 2 \leq 10.43 \mathrm{ng} / \mathrm{mL}$ & 2.18 & $(0.69-6.90)$ & 0.185 & & & \\
\hline $43 \mathrm{ng} / \mathrm{mL}<\mathrm{Q} 3 \leq 16.16 \mathrm{ng} / \mathrm{mL}$ & 1.08 & $(0.30-3.85)$ & 0.902 & & & \\
\hline $16.16 \mathrm{ng} / \mathrm{mL}<\mathrm{Q} 4$ & 4.36 & $(1.33-14.34)$ & 0.015 & & & \\
\hline \multicolumn{7}{|l|}{ Sex } \\
\hline Female (vs. male) & 0.69 & $(0.30-1.60)$ & 0.389 & 0.85 & $(0.38-1.91)$ & 0.691 \\
\hline \multicolumn{7}{|l|}{ Age } \\
\hline $60-69$ yr (vs. $\leq 59 y r)$ & 1.74 & $(0.59-5.13)$ & 0.314 & 1.92 & $(0.66-5.54)$ & 0.230 \\
\hline $70-79 y r(v s . \leq 59 y r)$ & 1.19 & $(0.38-3.79)$ & 0.764 & 1.13 & $(0.36-3.60)$ & 0.833 \\
\hline$\geq 80 \mathrm{yr}$ (vs. $\leq 59 \mathrm{yr}$ ) & 0.59 & $(0.13-2.63)$ & 0.490 & 0.64 & $(0.15-2.85)$ & 0.562 \\
\hline \multicolumn{7}{|l|}{ Average outdoor activity time, hr./day } \\
\hline $2-6$ (vs. <2) & 0.85 & $(0.34-2.11)$ & 0.729 & 0.97 & $(0.40-2.36)$ & 0.948 \\
\hline$>6$ (vs. <2) & 1.39 & $(0.46-4.26)$ & 0.560 & 1.65 & $(0.54-4.99)$ & 0.378 \\
\hline \multicolumn{7}{|l|}{ Hypertension } \\
\hline Yes (vs. no) & 2.27 & $(0.98-5.28)$ & 0.056 & 1.97 & $(0.87-4.47)$ & 0.103 \\
\hline \multicolumn{7}{|l|}{ Axial length } \\
\hline$\geq 24 \mathrm{~mm}$ (vs. <24 mm) & 0.24 & $(0.08-0.70)$ & 0.009 & 0.22 & $(0.07-0.63)$ & 0.005 \\
\hline
\end{tabular}

Hosmer \& Lemeshow model fit: Model 1, chi-square $=5.42, P=0.712$; Model 2, chi-square $=2.78, P=0.947$

25(OH) D, 25-hydroxyvitamin D; HTN, hypertension

Furthermore, lower serum 25(OH) D concentration was associated with longer $\mathrm{AL}$ and a higher risk of myopia, resulting in a significantly higher prevalence of myopia in individuals with vitamin D deficiency than in individuals with sufficient vitamin D levels $[35,36]$.

We found that total $25(\mathrm{OH})$ concentrations in aqueous humor and serum were not significantly correlated

Table 5 Multivariate linear regression analysis of factors associated with $25(\mathrm{OH}) \mathrm{D}$ concentrations in aqueous humor

\begin{tabular}{|c|c|c|c|}
\hline & \multicolumn{3}{|c|}{$\begin{array}{l}\text { Anterior chamber } 25(\mathrm{OH}) \mathrm{D} \\
\text { concentration }\end{array}$} \\
\hline & $\begin{array}{l}\text { Regression } \\
\text { coefficient }\end{array}$ & $95 \% \mathrm{Cl}$ & $P$ value \\
\hline \multicolumn{4}{|l|}{ Sex } \\
\hline Female vs (ref. male) & -2.79 & $(-5.05--0.53)$ & 0.016 \\
\hline \multicolumn{4}{|l|}{ Type of cataract } \\
\hline Diabetic cataract vs (ref. senile) & 2.68 & $(0.34-5.01)$ & 0.025 \\
\hline \multicolumn{4}{|c|}{ Average outdoor activity time (hr/day) } \\
\hline $2-6$ (ref. $<2)$ & -2.04 & $(-4.49-0.42)$ & 0.103 \\
\hline$>6$ (ref. <2) & -0.32 & $(-3.54-2.89)$ & 0.843 \\
\hline \multicolumn{4}{|l|}{ ECC (cells $\left./ \mathrm{mm}^{2}\right)$} \\
\hline $1000-2000$ vs (ref. <1000) & 7.47 & $(-0.68-15.63)$ & 0.072 \\
\hline$>2000$ vs (ref. <1000) & 3.3 & $(-4.16-10.76)$ & 0.383 \\
\hline
\end{tabular}

ECC endothelial cell count in cataract patients, suggesting that vitamin $\mathrm{D}$ in aqueous humor may not be affected by serum vitamin D concentration and that serum vitamin $\mathrm{D}$ concentrations may not be associated with intraocular diseases such as cataract. In addition, these findings could lead to additional studies determining whether vitamin $\mathrm{D}$ crosses the blood-aqueous humor barrier via a special transport system. Most (85-90\%) of the circulating 25(OH) D in serum is tightly bound to the $58 \mathrm{kDa}$ sized vitamin D-binding protein (VDBP), with a smaller percentage (10-15\%) loosely bound to albumin, and less than $1 \%$ circulating in free unbound form [37-39]. VDBPbound $25(\mathrm{OH}) \mathrm{D}$ may be transported to tear fluid by the megalin/cubilin transport system [40], which has been detected in animal lacrimal and accessory glands [18]. A study of 48 healthy subjects reported a correlation between $25(\mathrm{OH})$ D levels in serum and tear fluid, suggesting that serum vitamin D was transferred to tear fluid by the megalin/cubilin system present in lacrimal and accessory glands. Our results suggest, however, that the mechanisms involved in the synthesis and migration of vitamin $\mathrm{D}$ differ in aqueous humor and tear fluid. Investigation of this hypothesis requires further studies to determine whether megalin/cubilin is present in the eye, other than in the lacrimal and accessory glands. In addition, because the 
Table 6 Multivariate linear regression analysis of factors associated with 25(OH)D concentrations in serum

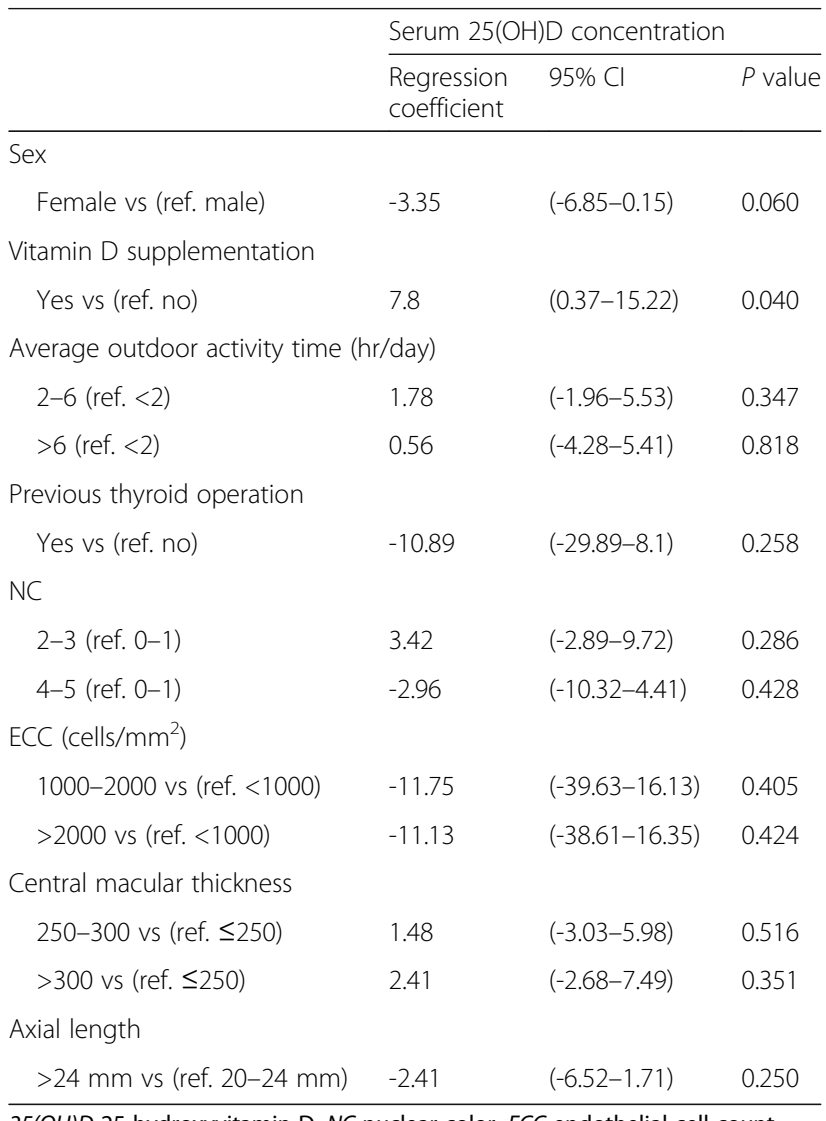

$25(\mathrm{OH}) \mathrm{D}$ 25-hydroxyvitamin $\mathrm{D}, \mathrm{NC}$ nuclear color, $E C C$ endothelial cell count

eye is exposed to the sun, it can produce or activate vitamin D [32], suggesting that the production of vitamin $\mathrm{D}$ in intraocular tissues containing lens epithelial cells and/or lens protein may explain the lack of correlation between vitamin $\mathrm{D}$ concentrations in aqueous humor and serum.

We found that the concentration of vitamin $\mathrm{D}$ in aqueous humor was significantly higher in patients with diabetic than senile cataract, a result confirmed by multivariate logistic regression analysis and multivariate linear regression analysis. Although this study was the first to measure vitamin $\mathrm{D}$ concentration in aqueous humor, a large-scale study involving 16,000 patients reported that serum $25(\mathrm{OH})$ D levels were inversely associated with the risk of nuclear cataract. We found that serum $25(\mathrm{OH})$ D concentrations did not differ significantly in patients with senile and diabetic cataract $(P<$ $0.686)$, whereas $25(\mathrm{OH}) \mathrm{D}$ concentration in aqueous humor was significantly higher in patients with diabetic than senile cataract. To explain this finding, we focused on the anti-cataractogenic role of vitamin $\mathrm{D}$, and the increases in inflammatory responses and oxidative stress in patients with diabetes. Vitamin D is reported to regulate the immune system and to suppress oxidative stress [41, 42]. Vitamin D exerts an anti-inflammatory effect by decreasing the proliferation of lymphocytes and natural killer cells and the secretion of several proinflammatory cytokines [41]. Additionally, calcitriol, the active metabolite of vitamin $\mathrm{D}$, was shown to act as a potent anti-oxidant [42]. In patients with diabetes, inflammatory responses are up regulated [43] and oxidative stress is much higher than normal [44], resulting in vascular and other complications. Vitamin D suppresses oxidative stress, which induces cataract $[45,46]$. Thus, inflammatory responses and oxidative stress were likely greater in the patients with diabetic than senile cataract, with the former showing greater increases in $25(\mathrm{OH}) \mathrm{D}$ levels in aqueous humor. The effect of diabetes on the blood-aqueous barrier [47] may explain the reason that vitamin D levels in the aqueous humor were higher in patients with diabetic than senile cataract. However, the reason that serum $25(\mathrm{OH}) \mathrm{D}$ concentrations did not differ in the two groups remains unclear; further studies are therefore required.

This study had several limitations. First, the number of patients was relatively small. Second, because most patients with diabetic cataract were elderly, we could not completely exclude the possibility that age was a confounding factor in the development of cataract. Third, we did not exclude the effects of insulin and various hypoglycemic drugs that could affect vitamin D concentrations in serum or aqueous humor. Fourth, we could not compare our patients with a control group of patients without cataracts, because, for ethical reasons, we could not obtain aqueous humor from the latter. To elucidate the role of vitamin D in aqueous humor, a larger clinical study, including a control group of patients without cataracts, is required. Finally, total $25(\mathrm{OH}) \mathrm{D}$ levels in this study were not measured by LC-MS/MS, the method considered the gold standard for measuring $25(\mathrm{OH}) \mathrm{D}$ concentrations. However, the assay used in this study, the Elecsys Vitamin D Total Kit with the Cobas e602 module (Roche Diagnostics), is reported to yield results comparable to those of the LC-MS/MS method [48].

\section{Conclusions}

In conclusion, this study is the first to show that vitamin $\mathrm{D}$ is present in aqueous humor and to report its concentrations in groups of patients with diabetic and senile cataract. We found that $25(\mathrm{OH})$ concentrations in aqueous humor and serum did not correlate with each other, whereas $25(\mathrm{OH}) \mathrm{D}$ concentrations in aqueous humor were higher in patients with diabetic than senile cataract. These findings suggest that studies of the effects of vitamin $\mathrm{D}$ in the eye should include measurements of vitamin $\mathrm{D}$ levels in aqueous humor. 


\section{Abbreviations}

1a, $25(\mathrm{OH}) \mathrm{D}: 1$ a, 25-dihydroxyvitamin D; $25(\mathrm{OH}) \mathrm{D}$ : 25-hydroxyvitamin D; ACD: Anterior chamber depth; ACV: Anterior chamber volume; AL: Axial length; CCT: Central corneal thickness; Cl: Confidence interval; HPLC: High performance liquid chromatography; IQR: Interquartile range; LC-MS/ MS: Liquid chromatography with tandem mass spectrometry; OR: Odds ratio; SVCT2: Sodium-dependent vitamin C transporter 2; TBUT: Tear breakup time; VDBP: Vitamin D-binding protein

\section{Acknowledgments}

The authors acknowledge the support of a National Research Foundation of Korea (NRF) grant funded by the Korea government (MSIT) (2018R1C1B5040593) and by the Biomedical Research Institute fund (GNUHBRIF-2017-0006) of Gyeongsang National University Hospital, and the Biomedical Research Institute fund (GNUHBRIF-2019-0003) of Gyeongsang National University Hospital.

\section{Authors' contributions}

CMC designed the project, performed experiments, and wrote the manuscript. KRB performed statistical analysis and wrote the manuscript. AJY collected the clinical data. YWS performed statistical analysis and wrote the manuscript. KSJ designed the project, performed experiments, wrote the manuscript, and supervised the project. All authors read and approved the final version of the manuscript.

\section{Funding}

CMC was supported by a National Research Foundation of Korea (NRF) grant funded by the Korea government (MSIT) (2018R1C1B5040593) and by the Biomedical Research Institute fund (GNUHBRIF-2017-0006) of Gyeongsang National University Hospital. And KSJ was supported by the Biomedical Research Institute fund (GNUHBRIF-2019-0003) of Gyeongsang National University Hospital. No funding bodies had any role in study design, data collection and analysis, decision to publish, or preparation of the manuscript.

\section{Availability of data and materials}

The data of the current study are available from the corresponding author on reasonable request.

\section{Ethics approval and consent to participate}

This study was approved by the Ethics Committee of the Gyeongsang National University Hospital, and conformed to the tenets of the Declaration of Helsinki. Each patient's parent or guardian signed a consent form.

\section{Consent for publication}

We confirm that all participants' parents/legal guardians in our study provided written informed consent for the medical information to be published. A copy of the written consent is available for review by the editor of this journal.

\section{Competing interests}

The authors declare that they have no competing interests.

\section{Author details}

'Department of Laboratory Medicine, Gyeongsang National University Hospital and Gyeongsang National University College of Medicine, Jinju, South Korea. ${ }^{2}$ Institute of Health Science, Gyeongsang National University, Jinju, South Korea. ${ }^{3}$ Department of Preventive Medicine, Gyeongsang National University Hospital and Gyeongsang National University College of Medicine, Jinju, South Korea. ${ }^{4}$ Department of Ophthalmology, Gyeongsang National University Hospital and Gyeongsang National University College of Medicine, 79 Gangnam-ro, Jinju-si, Gyeongsangnam-do 52727, South Korea.

Received: 23 March 2019 Accepted: 27 December 2019

\section{Published online: 06 January 2020}

\section{References}

1. Hollis BW, Wagner CL. Clinical review: the role of the parent compound vitamin D with respect to metabolism and function: why clinical dose intervals can affect clinical outcomes. J Clin Endocrinol Metab. 2013;98:4619-28.

2. Prietl B, Treiber G, Pieber TR, Amrein K. Vitamin D and immune function. Nutrients. 2013;5:2502-21.
3. Kienreich $K$, et al. Vitamin D and cardiovascular disease. Nutrients. 2013;5:3005-21.

4. Pines A. Vitamin D and health issues--questioned benefits. Climacteric. 2014; 17:657-9.

5. Mitri J, Pittas AG. Vitamin D and diabetes. Endocrinol Metab Clin N Am. 2014;43:205-32.

6. Valipour G, Saneei P. Esmaillzadeh A. Serum vitamin D levels in relation to schizophrenia: a systematic review and meta-analysis of observational studies. J Clin Endocrinol Metab. 2014;99:3863-72.

7. Hammami MM, Yusuf A. Differential effects of vitamin D2 and D3 supplements on 25-hydroxyvitamin D level are dose, sex, and time dependent: a randomized controlled trial. BMC Endocr Disord. 2017;17:12.

8. Holick MF. Vitamin D deficiency. N Engl J Med. 2007;357:266-81.

9. Holick MF. High prevalence of vitamin D inadequacy and implications for health. Mayo Clin Proc. 2006;81:353-73.

10. Malabanan A, Veronikis IE, Holick MF. Redefining vitamin D insufficiency. Lancet. 1998;351:805-6.

11. Cavalier E, Rousselle O, Ferrante N, Carlisi A, Le Goff C, Souberbielle JC. Technical and clinical evaluation of the VITROS (R) immunodiagnostic products $25-\mathrm{OH}$ vitamin D Total assay--comparison with marketed automated immunoassays and a liquid chromatography-tandem mass spectrometry method. Clin Chem Lab Med. 2013;51:1983-9.

12. Abdel-Wareth $L$, et al. Total vitamin $D$ assay comparison of the Roche Diagnostics "vitamin D total" electrochemiluminescence protein binding assay with the Chromsystems HPLC method in a population with both D2 and D3 forms of vitamin D. Nutrients. 2013;5:971-80.

13. Yazar $\mathrm{S}$, et al. Myopia is associated with lower vitamin D status in young adults. Invest Ophthalmol Vis Sci. 2014;55:4552-9.

14. Jee D, Kang S, Yuan C, Cho E, Arroyo JG. Epidemiologic survey Committee of the Korean Ophthalmologic S. serum 25-Hydroxyvitamin D levels and dry eye syndrome: differential effects of vitamin D on ocular diseases. PLoS One. 2016;11:e0149294.

15. Yildirim P, Garip Y, Karci AA, Guler T. Dry eye in vitamin D deficiency: more than an incidental association. Int J Rheum Dis. 2016;19:49-54.

16. Payne JF, et al. Vitamin D insufficiency in diabetic retinopathy. Endocr Pract. 2012;18:185-93.

17. Goksugur SB, et al. Tear and serum vitamin D levels in children with allergic rhinoconjunctivitis. Allergol Immunopathol (Madr). 2015;43:533-7.

18. Lu X, et al. Vitamin D in Tear Fluid. Invest Ophthalmol Vis Sci. 2015:56:5880-7.

19. Sethu S, Shetty R, Deshpande K, et al. Correlation between tear fluid and serum vitamin D levels. Eye Vis (Lond). 2016;3:22.

20. To CH, Kong CW, Chan CY, Shahidullah M, Do CW. The mechanism of aqueous humour formation. Clin Exp Optom. 2002;85:335-49.

21. Xiang $\mathrm{M}$, et al. Identification of proteins in the aqueous humor associated with cataract development using iTRAQ methodology. Mol Med Rep. 2017;15:3111-20.

22. Kulaksizoglu S, Karalezli A. Aqueous humour and serum levels of nitric oxide, malondialdehyde and total antioxidant status in patients with type 2 diabetes with proliferative diabetic retinopathy and nondiabetic senile cataracts. Can J Diabetes. 2016;40:115-9.

23. Ji Y, Rong $X$, Ye H, Zhang K, Lu Y. Proteomic analysis of aqueous humor proteins associated with cataract development. Clin Biochem. 2015;48:1304-9.

24. Song P, Wang H, Theodoratou E, Chan KY, Rudan I. The national and subnational prevalence of cataract and cataract blindness in China: a systematic review and meta-analysis. J Glob Health. 2018;8:010804.

25. Lansingh VC, Carter MJ, Martens M. Global cost-effectiveness of cataract surgery. Ophthalmology. 2007;114:1670-8.

26. Hodge WG, Whitcher JP, Satariano W. Risk factors for age-related cataracts. Epidemiol Rev. 1995;17:336-46.

27. Haddad NM, Sun JK, Abujaber S, Schlossman DK, Silva PS. Cataract surgery and its complications in diabetic patients. Semin Ophthalmol. 2014;29:329-37.

28. Gupta VB, Rajagopala M, Ravishankar B. Etiopathogenesis of cataract: an appraisal. Indian J Ophthalmol. 2014;62:103-10.

29. Jacques PF, Hartz SC, Chylack LT Jr, McGandy RB, Sadowski JA. Nutritional status in persons with and without senile cataract: blood vitamin and mineral levels. Am J Clin Nutr. 1988:48:152-8.

30. Roche Diagnostics, Elecsys vitamin D Total Electrochemiluminescence binding assay reagent insert, Mannheim, Germany, 2017.

31. Templeton GF. A two-step approach for transforming continuous variables to normal: implications and recommendations for IS research. CAIS. 2011;28:41-58

32. Reins RY, McDermott AM. Vitamin D: Implications for ocular disease and therapeutic potential. Exp Eye Res. 2015;134:101-10. 
33. Dadaci Z, Borazan M, Kiyici A, Oncel AN. Plasma vitamin D and serum total immunoglobulin E levels in patients with seasonal allergic conjunctivitis. Acta Ophthalmol. 2014;92:e443-6.

34. Kurtul BE, Ozer PA, Aydinli MS. The association of vitamin D deficiency with tear break-up time and Schirmer testing in non-Sjogren dry eye. Eye (Lond). 2015;29:1081-4.

35. Jee D, Kim EC. Association between serum 25-hydroxyvitamin D levels and age-related cataracts. J Cataract Refract Surg. 2015;41:1705-15.

36. Fang $F$, et al. High prevalence of vitamin D deficiency and influencing factors among urban and rural residents in Tianjin, China. Arch Osteoporos. 2018;13:64.

37. Bhan I, et al. Bioavailable vitamin D is more tightly linked to mineral metabolism than total vitamin $\mathrm{D}$ in incident hemodialysis patients. Kidney Int. 2012;82:84-9.

38. Bikle DD, Gee E, Halloran B, Kowalski MA, Ryzen E, Haddad JG. Assessment of the free fraction of 25 -hydroxyvitamin $D$ in serum and its regulation by albumin and the vitamin D-binding protein. J Clin Endocrinol Metab. 1986;63:954-9.

39. Bikle DD, Siiteri PK, Ryzen E, Haddad JG. Serum protein binding of 1,25dihydroxyvitamin D: a reevaluation by direct measurement of free metabolite levels. J Clin Endocrinol Metab. 1985;61:969-75.

40. Christensen El, Birn H. Megalin and cubilin: multifunctional endocytic receptors. Nat Rev Mol Cell Biol. 2002;3:256-66.

41. Palomer X, Gonzalez-Clemente JM, Blanco-Vaca F, Mauricio D. Role of vitamin $\mathrm{D}$ in the pathogenesis of type 2 diabetes mellitus. Diabetes Obes Metab. 2008:10:185-97.

42. Lin AM, Chen KB, Chao PL. Antioxidative effect of vitamin D3 on zincinduced oxidative stress in CNS. Ann N Y Acad Sci. 2005;1053:319-29.

43. Lontchi-Yimagou E, Sobngwi E, Matsha TE, Kengne AP. Diabetes mellitus and inflammation. Curr Diab Rep. 2013;13:435-44.

44. Pitocco D, Tesauro M, Alessandro R, Ghirlanda G, Cardillo C. Oxidative stress in diabetes: implications for vascular and other complications. Int J Mol Sci. 2013:14:21525-50.

45. Selin JZ, et al. Are increased levels of systemic oxidative stress and inflammation associated with age-related cataract? Antioxid Redox Signal. 2014;21:700-4

46. $L i \mathrm{~L}$, et al. Oxidative stress and antioxidant status in older adults with early cataract. Eye (Lond). 2009;23:1464-8.

47. Kheir WJ, Sheheitli HA, Hamam RN. Intraocular inflammation in diabetic populations. Curr Diab Rep. 2017;17:83.

48. Knudsen CS, Nexo E, Hojskov CS, Heickendorff L. Analytical validation of the Roche 25-OH vitamin D Total assay. Clin Chem Lab Med. 2012;50:1965-8.

\section{Publisher's Note}

Springer Nature remains neutral with regard to jurisdictional claims in published maps and institutional affiliations.

Ready to submit your research? Choose BMC and benefit from:

- fast, convenient online submission

- thorough peer review by experienced researchers in your field

- rapid publication on acceptance

- support for research data, including large and complex data types

- gold Open Access which fosters wider collaboration and increased citations

- maximum visibility for your research: over $100 \mathrm{M}$ website views per year

At $\mathrm{BMC}$, research is always in progress.

Learn more biomedcentral.com/submissions 